\title{
A Closer Look at Different Aspects of Language Teaching/Learning and Learner Identity
}

\author{
Parviz Maftoon \\ Department of English, Science and Research Branch, Islamic Azad University, Tehran, Iran \\ Email: pmaftoon@ srbiau.ac.ir \\ Saeid Najafi Sarem (Corresponding author) \\ Department of English, Science and Research Branch, Islamic Azad University, Tehran, Iran \\ Email: s_najafisarem@yahoo.com \\ Hadi Hamidi \\ Department of English, Science and Research Branch, Islamic Azad University, Tehran, Iran \\ Email: hamidi_tefl@yahoo.com
}

\begin{abstract}
Along with the changes in the realm of language teaching and learning in $1960 \mathrm{~s}$ from the previous structuralist teacher-centered methodologies and the subsequent emergence of social-constructivist approaches, learners came to be considered as the key in the field. As a result, learner-centered approaches were developed and special attention was given to sociological and anthropological dimensions of second language learning. Due to these shifts of focus, such concepts as learner identity came to attract the attention of language teachers and scholars. Gee (2001) defines identity as "a certain 'kind of person' or even as several different 'kinds' at once ... at a given time and place" (p. 99). Thus, second language scholars tried to investigate the possible relationship between the language learner and the larger social world. In the same line, the present article attempts to represent a description of the main variables in relation to learner identity aimed at shedding light on comprehending the theoretical points significant in the field. Then, the article goes on to discuss the role of identity and its possible influences in the field of second language teaching and learning. Finally, the implications and applications in the field are discussed.
\end{abstract}

Index Terms - language teaching/learning, identity types, learner identity, community of practice

\section{INTRODUCTION}

Due to a shift of focus from the predominantly psycholinguistic approaches to SLA to include a greater focus on sociological and anthropological dimensions of second language learning, particularly with reference to sociocultural, poststructural, and critical theory, such concepts as learner identity came to attract the attention of language scholars (Norton, 2006). Norton (1997) uses the term identity to refer to "how people understand their relationship to the world, how that relationship is constructed across time and space, and how people understand their possibilities for the future". The relationship between language learning and identity is of great interest to scholars in the fields of second language acquisition (SLA), language education, applied linguistics and sociolinguistics. According to Norton and Toohey (2001) the concept of identity concentrates on sociological and cultural dimensions of language learning which has often been called the "social turn" in second language acquisition. Norton (2006) adds that researchers of second language identity have been interested not only in linguistic input and output in SLA, but in the relationship between the language learner and the larger social world. In particular, these researchers have examined the diverse social, historical, and cultural contexts in which language learning takes place and how learners negotiate and sometimes resist the diverse positions those contexts offer them.

As Norton (2006) states one of the important issues which has fascinated many researchers in second language identity is the extent to which relations of power within classrooms and communities promote or constrain the process of language learning. It is argued that the extent to which a learner speaks or is silent or writes, reads, or resists has much to do with the extent to which the learner is valued in any given institution or community. In this regard, such factors as gender, race, class, ethnicity, and sexual orientation may pose inequities in the social practices and thus affect learners to behave in particular ways. As such, learners don't like to be marginalized and try to avoid it through covert and overt acts of resistance. What is of central interest to researchers of second language identity is that the very articulation of power, identity, and resistance is expressed in and through language. Language is thus more than a system of signs; it is a social practice in which experiences are organized and identities negotiated (Norton, 2006). Taking these points into account, the present article is of twofold. First, elaborating on the main points related to the learner identity, it is going to take a critical look at this phenomenon. Second, it attempts to shed light on understanding 
the relationship between the learner identity and different aspects language teaching and to discuss the implications it bears to the process of language learning and teaching.

\section{THEORETICAL INFLUENCES}

Second language research in the area of identity is indebted to and affected by the works of scholars like Bakhtin, Bourdieu, Weedon, as well as Lave and Wenger. Bakhtin (1981) takes the position that language needs to be investigated not as a set of idealized forms independent of their speakers or their speaking, but rather as situated utterances in which speakers, in dialogue with others, struggle to create meanings. For Bakhtin, the notion of the individual speaker is a fiction, as he sees all speakers constructing their utterances jointly on the basis of their interaction with listeners in both historical and contemporary, and both actual and assumed, communities. In this view, the allocation of the words of others is a complex process in which words are not neutral but express particular predispositions and value systems.

The second scholar who has influenced research concerning identity is Pierre Bourdieu, a contemporary French sociologist. Bourdieu (1984) focuses on the often unequal relationships between interlocutors and the importance of power in structuring speech. He suggests that the value ascribed to speech cannot be understood apart from the person who speaks and that the person who speaks cannot be understood apart from larger networks of social relationships. In this view, when a person speaks, the speaker wishes not only to be understood, but to be believed, obeyed, and respected. However, the speaker's ability to command the attention of the listener is unequally distributed because of the symbolic power relations between them.

Research in the field of identity has been also impacted by the scholar, Christine Weedon. The work of Weedon (1987), like that of Bakhtin and Bourdieu, is centrally concerned with the conditions under which people speak, within both institutional and community contexts. Like other poststructuralist theorists, Weedon emphasizes the central role of language in her analysis of the relationship between the individual and the social, arguing that language not only defines institutional practices, but also serves to construct our sense of ourselves and our "subjectivity" (Weedon, 1987, p. 21). Weedon notes that the terms subject and subjectivity signify a different conception of the individual than that associated with humanist conceptions of the individual dominant in Western philosophy. While humanist conceptions of the individual presuppose that every person has an essential, unique, fixed, and coherent 'core,' poststructuralism depicts the individual (i.e., the subject) as diverse, contradictory, dynamic, and changing over historical time and social space.

Finally, Lave and Wenger were two other anthropologists who shifted the view of learners as individuals to seeing them as members of social and historically constituted communities. Lave and Wenger (1991) argue that what they call "situated learning" is an integral and inseparable part of social practice, as newcomers are mentored (helped and advised) into the performance of community practices. They introduced the notion of "legitimate peripheral participation" by which they meant that communities are composed of participants who differentially engage with the practices of their community and that conditions vary with regard to many factors as ease of access to expertise, to opportunities for practice, to consequences for error in practice, and so on.

Norton and Toohey (2001) have referred to these theories saying that from this perspective, then, educational research might focus not so much on assessing individual 'uptake' of particular knowledge or skills, but on the social structures in particular communities and on the variety of positionings available for learners to occupy in those communities. Rather than seeing language learning as a gradual individual process of internalizing a neutral set of rules, structures, and vocabulary of a standard language, the work of Bakhtin, Bourdieu, Weedon, and Lave and Wenger offers applied linguists ways to think differently about language learning. Such theory suggests that second language learners need to struggle to appropriate the voices of others; they need to learn to command the attention of their listeners; they need to negotiate language as a system and as a social practice; and they need to understand the practices of the communities with which they interact. Drawing on such theory, becoming a 'good' language learner is seen to be a much more complicated process than earlier research had suggested (Norton \& Toohey, 2001).

\section{IDENTITY AND LANGUAGE LEARNING}

In modern sociological and anthropological theories of language learning and teaching, learners' identity has been considered as a crucial factor which can pose significant effects on both teaching practices as well as learning outcomes. Norton (1995) defines identity as the ongoing sense the self has of who it is, as conditioned through its ongoing interactions with others. It is how the self conceives of itself, and labels itself. Chen and Ferdonia (2010) point out that identity constructs and is constructed by language. According to Morgan (1996) in contemporary theory on language learning and teaching, the identity of the language learner addresses the ways in which language learners understand their relationship to the social world, how that relationship is constructed across time and space, and how the learner understands possibilities for the future.

Norton and Toohey (2001) believe that the identity of the language learner is theorized as multiple, a site of struggle, and subject to change. The diverse conditions under which language learners speak, read, or write the second language are influenced by relations of power in different sites; learners who may be marginalized in one site may be highly valued in another. For this reason, as Norton and Toohey (2001) mention, every time language learners interact in the 
second language, whether in the oral or written mode, they are engaged in identity construction and negotiation. However, structural conditions and social contexts are not entirely determined. Through human agency, language learners who struggle to speak from one identity position may be able to reframe their relationship with their interlocutors and claim alternative, more powerful identities from which to speak, thereby enhancing language learning.

\section{Perspectives on Identity: Community of Practice}

One of the scholars who is interested in the concept of identity is Gee. He focuses his work on situated identity. Gee (2001) defines identity as "a certain 'kind of person' or even as several different 'kinds' at once . . a a given time and place" (p. 99). This definition indicates that identity is a state of being; thus, it is situated in disclosing social contexts. As Norton (2000) states identity bears the characteristics of being dynamic and multiple, as it shifts from one context to the next, and various identities may coexist. In order to understand what situated identity accurately means, we have to know the concept of community of practice.

Wenger (1998) defines a community of practice through the dimensions of (a) mutual engagement, (b) joint enterprise, and (c) shared repertoire (a list of works that a person or group is ready to perform). The boundaries and the development of a community of practice are continuously negotiated by members bound together in its joint construction (Wenger, 1998). Lave and Wenger (1991) discuss how the dynamic membership adopted by and interactions among learners contribute to learning. They argue that the familiarity with certain beliefs and behaviors particular to a community of practice defines the role taken by a learner (e.g., a central or peripheral participant). Moreover, the idea of community of practice implies that "learning involves the construction of identities"; that is to say, learners need to construct "not only a relation to specific activities, but also a relation to social communities" (Lave \&Wenger, 1991, p. 53). Such relation, as a result, leads to different learning experiences and outcomes. Thus, community of practice provides the context to understand the situated identities each member takes and his/her engagement in learning.

\section{POWER RELATION AND IDENTITY NEGOTIATION}

The identity of the language learner is supposed as multiple, a site of struggle, and subject to change. According to Norton (2000), the various conditions under which language learners speak, read, or write the second language are partly shaped by relations of power in different sites; learners who may be marginalized in one site may be extremely appreciated in another site. For such reason, as Norton emphasizes, every time language learners interact in the second language, whether in the oral or written mode, they are involved in identity construction and negotiation. Nevertheless, structural conditions and social contexts are not entirely ascertained. Through human agency, language learners who struggle to speak from one identity position may be able to reshape their relationship with their interlocutors and claim alternative, more powerful identities from which to speak, and as a result improving language learning.

Norton (2000) defines power as "the socially constructed relations among individuals, institutions and communities through which symbolic and material resources in a society are produced, distributed and validated" (p. 7). In Norton's (2000) view symbolic resources refer to nonphysical resources such as language proficiency. Material resources refer to tangible resources such as books, tools, and computers. Power relations between a teacher and student or among peers, may be of various nature. According to Blackledge and Pavlenko (2001) identity is the product of the negotiation between an individual's identity claims and the availability of identity choices determined by the power relations in various social contexts. Hawkins (2004) states that on the one hand, individuals claim desirable and appropriate identities based primarily on "the subjects' understandings of the social world within which they are positioned" (p. 18). On the other hand, based on Mitchell and Myles (2004), "the social structure of communities and the power relations obtaining within them define the learning possibilities available to members" (p. 241). Such negotiation is referred to as the continuous struggles between positioning and repositioning. According to Toohey, Day and Manyak (2007) the notion of positioning issues form the recognition that people always communicate more than semantic content through their speech and non-verbal behavior. Through our choices of languages, dialects, genres, styles, modes, intonations, and timing, we create certain social positions for ourselves and simultaneously position others in particular ways. These acts of positioning occur in and contribute to a dynamic and often inequitable social terrain. The concept of identity position refers to this ongoing process of positioning: Through what we say and do, we place ourselves and are placed by others in positions that influence our identities (the ways we view ourselves and our relationship to the world).

Hawkins (2004) mentions that power relations embedded in different social contexts are the driving forces that shape the individuals' awareness of how they are positioned, what identity roles are accessible, what opportunities are available for negotiation, and what kind of learning takes place. While it is essential to understand situated identities in light of power relations, Blackledge and Pavlenko (2001) point out the limitations of the notion of identity negotiation, as there are cases in which identities may not be negotiable or relevant in the historical or social contexts. They assert that it is important to differentiate the following three types of power relations: (a) "the power differential is such that resistances of negotiation [are] impossible," (b) the power relations "which evoke resistance," and (c) the power relations "where the interlocutors or the negotiating parties may enjoy a relatively equal power balance" (p. 250). Given 
the intricate relation between power relations and identity negotiation, it is critical to identify the nature of power relations in order to understand the possibility for and effectiveness of identity negotiation.

As it is clear based on the above points, power relations and power negotiation within a group, which in this context is called community of practice, affect learners' identity towards either positive learning outcomes or negative ones. As was mentioned, if the interlocutors or the negotiating parties possess a relatively equal power relationship, it makes them feel at ease and negotiate their identities freely which, in turn, leads to efficient language learning. However, if the power relation in the group is in favor of one party, the other participant may not express his/her identity openly. In this case, identity negotiation fails and this influences language learning negatively.

\section{IDENTITY INVESTMENT}

Learning about power relations, it is found that individual desires have also a significant role in the process of identity negotiation. Research findings confirm this position. Based on the findings obtained through a study on immigrant women in Canada, Norton (2000) proposed that instead of the discussion of motivation in the process of SLA, it is better to propose the concept of identity investment as a way to recognize the complex relationship between power, identity, and language learning. Most theories at the time assumed that motivation was a character trait of the individual language learner and that learners who failed to learn the target language were not sufficiently committed to the learning process. Norton (2000) states that such theories did not do justice to the identities and experiences of the language learners. Therefore the notion of motivation was replaced by the more fruitful concept of investment. The notion of investment, inspired by the work of Bourdieu, signals the socially and historically constructed relationship of learners to the target language and their often uncertain (having both positive and negative feelings towards a subject) desire to learn and practice it. If learners 'invest' in the target language, they do so with the understanding that they will acquire a wider range of symbolic and material resources, which will in turn increase the value of their cultural capital. Unlike notions of instrumental motivation, which conceive of the language learner as having a unitary, fixed, and ahistorical 'personality,' the notion of investment conceives of the language learner as having a complex identity, changing across time and space, and reproduced in social interaction. An investment in the target language is best understood as an investment in the learner's own identity (Norton, 2000). Accordingly, as Norton (2000) states it is assumed that "a learner has multiple desires mediated by his/her perception of the power relations in context, and his/her investment in learning should be viewed as "an investment in a learner's own identity" (p. 11).

\section{Sociocultural APPROACH TO LEARNER IDENTITY}

Sociocultural perspectives on learning devote particular attention to the concept of learner identity. Hegel is identified as the originator of many socioculturally-oriented approaches to identity, including his identification of relationships, interaction, activity, discourse and recognition as essential constituents of an identity (Benwell \& Stokoe, 2006, cited in Falsafi \& Coll, 2010). According to Falsafi and Coll (2010) the theories applied in the conceptualization of learner identity mainly use three recurring aspects of the sociocultural approach to identity. These are the theories that identify the discursive or rhetorical nature of identity those which view identity construction as deeply embedded in activity and as part of social practice and finally approaches that emphasize recognition as essential to identity construction. The activity is defined by its object, which in turn defines the nature or the type of identity. In other words, the activity defines the content of the identity or the meanings that are being constructed about oneself. When playing football the meanings that the individual constructs about himself concern his recognition as a team player, a skilled ballplayer, an individualist goal hunter, etc., whereas the activity of coaching the football team drives the construction of meanings about himself as an instructor, motivator, game strategist, etc. While the activity provides the identity with meaning material, the discursive or rhetorical features of identity is in our view a reference to the mode in which the identity is being constructed. Falsafi and Coll (2010) suggest that discourse is the primary mode of identity construction, but not the only, since non-discursive actions, e.g. gestures, physical positioning, level of exposure to the surrounding etc., also are used. The mode of construction is related to the sight of identity construction, that is to say, whether it is taking place within the activity (participation in the classroom) or outside of the activity (talking about the participation in the classroom). Finally, they identify the notion of recognition as essential to any conceptualization of identity construction. In order to be, the individual requires the co-recognition of himself and others of this being. Hence, having an identity is to have a sense of recognition as someone. The meanings that are being constructed about oneself need to be recognized or else they cannot endure throughout and beyond the activity. Yet another shared feature of most of the socioculturally-oriented approaches is the emphasis on the two-dimensional nature of an identity as part individual and part social. The extent to which the individual and social are emphasized differs between the perspectives, and the operationalization of the distinction between the two dimensions and their point of overlap seems to be an ongoing theoretical and empirical challenge. However, regardless of other differences, this two dimensional conceptualization of identity seems to be a common denominator of most socio-culturally oriented approaches to identity construction. In Vygotskian terms, this specific feature could be expressed as the connection between the interpsychological and intrapsychological processes of identity construction. This implies that though an identity most certainly is experienced as a personal resource, the origin of its constituents, its value and its mediating function are socioculturally defined and 
constructed through relations. It takes at least two to construct an identity, but no matter how social and relational its construction and use always requires the subjective experience of an individual (Falsafi \& Coll, 2010).

\section{TYPES OF IDENTITY}

Joseph (2004) mentions three types of identity namely ethnic, national, and racial identity. Ethnic identity is focused more on common descent and on a cultural heritage shared because of common descent, than on political aspirations for autonomy. National identity is focused on political borders and autonomy, often justified by arguments centered on shared cultural heritage, but where the ethnic element is inevitably multiple. Finally, the racial identity - now a concept virtually taboo in American discourse (and this taboo itself represents an identity phenomenon in need of interrogation and discussion) - focused, like ethnic identity, on common descent (origin and nationality) and cultural heritage, but conceived on a large scale, for example 'black' identity as opposed to Indian identity.

Different authors have proposed different categorizations for learners' identity; however, all of them agree on the existence of multiple identities all at once at one space and time. According to Osguthorpe (2006) there are at least five different kinds of identity that are influenced by learning, namely professional, personal, talent, character and learner identity. From another perspective, identity can be categorized into social, cultural as well as ethnic or racial identity all affecting the process of learning in certain ways. However, learner identity is considered as the key in the learning process and is affected by all other types or can be regarded as an umbrella term which covers all the other categories. According to Osguthorpe (2006) the learner identity is affected by every new learning experience and he claims that all the other identities revolve around this one. A change and development in any of the other identities depends on the condition of the learner identity. Osguthorpe's definition of the learner identity focuses on the general long-term perception that one has of oneself as someone who easily can learn whatever necessary or as someone who has to overcome problems in order to learn.

According to Gumperz (1982) besides our uniquely personal sense of self, we also have social identities based upon the various groups to which we belong. Thus, we can maintain and enhance self-esteem through valued social affiliations, as well as by purely personal activities and achievements. According to the theory, it follows that withingroup favoritism is predictable since it reflects and supports the particular 'us and them' boundaries that can heighten feelings of individual worth. Gumperz (1982) believes that in-group solidarity should be expected to strengthen at times when one's sense of worth is threatened or tenuous. Based on Benwell and Stokoe (2006) social identity theory explores the phenomenon of the 'ingroup' and 'outgroup', and is based on the view that identities are constituted through a process of difference defined in a relative or flexible way dependent upon the activities in which one is engaged. Put simply, the ingroup is the one to which an individual 'belongs' and the 'outgroup' is seen as 'outside' and different from this group. Pierce (1995) defines social identity as "the relationship between the individual and the larger social world, as mediated through institutions such as families, school, workplaces, social services, and law courts" (p. 23). Three defining characteristics of social identity according to Pierce (1995) include: the multiple nature of identity, identity as a site of struggle, and identity as changing over time. Peirce separates "social identity" from "cultural identity," which she defines as "the relationship between individuals and members of a particular ethnic group who share a common history, a common language, and similar ways of understanding the world" (p. 23).

As Atkinson (1999) has noted, past theories of cultural identity tended to essentialize and regard identities in problematic ways. In more recent years, however, the difference between social and cultural identity is seen to be theoretically more fluid, and the intersections between social and cultural identities are considered more significant than their differences. In recent second language research, as was mentioned previously, identity is seen as socioculturally constructed, and scholars draw on both institutional and community practices to understand the conditions under which language learners speak, read, and write the target language. Duff and Uchida (1997), indeed, collapsed the distinctions between the social and the cultural by arguing for a sociocultural theory of identity in which identities and beliefs are co-constructed, negotiated, and transformed on a regular basis through language.

As Cummins (2000) states current research on second language identity conceives of identity as dynamic, contradictory, and constantly changing across time and place. Indeed, a recurring theme throughout much of the research is that of 'transition.' Many of the participants in research projects on second language identity are undergoing significant changes in their lives, whether moving from one country to another or from one institution to the next. Such transitions can be productive for language learning, providing learners with enhanced skills at negotiating bilingual identities; other transitions can be more problematic, as learners struggle to accommodate changing expectations in different institutional contexts. In such changing sets of circumstances, identities that might be seen as contradictory may, in point of fact, be constructed within contexts that are themselves sites of struggle (Cummins, 2000).

\section{RESEARCH ON IDENTITY}

Researchers of second language identity have become interested not only in the conditions under which language learners speak, but in the extent to which identities and investments structure their engagement with texts. According to Norton (2006) there is growing recognition that when a second language learner reads or writes a text, both the comprehension and construction of the text is mediated by the learner's investment in the activity and the learner's 
sociocultural identity. A lot of research has been done in this area of which two are mentioned here. For example, Norton Peirce and Stein (1995) demonstrate how the meaning of a South African reading comprehension text shifted when the social conditions under which it was read changed. They argue that the changing social occasions created different kinds of investments on the part of the students, and as the students' identities shifted from compliance to resistance, so did their interpretation of the text. Lam (2000) studied the Internet correspondence of a Chinese immigrant teenager in the United States who entered into transnational communication with a group of peers. She demonstrates how this experience of what she calls textual identity related to the student's developing identity in the use of English.

According to Toohey (2001, cited in Chen, 2010) in general, three bodies of research have been conducted in order to investigate identity. The first body of research examines the impact of school practices on identity construction. These studies suggest that classroom practices along with many other school practices, as well as with larger, societal ones should not lead to the supposition that identities are natural or inevitable. The second body of research focuses on the social relations among learners or between a teacher and student. Implications of this work indicate that different types of social relations impose different identities on learners, which leads to different learning outcomes. A third perspective examines social and school discourses to which learners are subjected and the agency they exercise to negotiate their identities. It implies that discourse and power are often interrelated in shaping learners' senses of selves. These studies with linguistically diverse students at different ages suggest that school practices, social relations among members, and social and school discourses are crucial factors in understanding learners' identity construction and their investment in new language and literacy (Toohey, 2000, cited in Chen, 2010).

\section{CONCluding Remarks}

Through the above literature, we took a critical detailed look at the role of identity in relation to second language learning and teaching. Learner identity, as an important characteristic, has a crucial effect on the teaching practices as well learning outcomes. According to Chavous (2006) academic engagement requires linking one's personal identity to the roles of student and learner, showing sustained curiosity and interest in class, and displaying intense efforts in learning tasks. Based on Norton (1997) a language learner's identity may help him/her become less/more motivated in language learning. According to Osguthorpe (2006) the learner identity is affected by every new learning experience. He defines learner identity as the general long term perception that one has of oneself as someone who easily can learn whatever necessary or as someone who has to overcome problems in order to learn. Getting familiar with the concept of identity as both an individual and a social variable, certain implications deserve mentioning in relation to educational and teaching practices which bear significant outcomes both for language teachers and educational authorities.

- One important thing teachers should notice is that every learner comes to class with a different linguistic background as well as a specific identity which is culturally bound. Even, identity conflict exists not only between home and school communities but also among various school/university communities. Therefore, teachers should try to construct a collaborative environment in which all learners with different identities feel comfortable to freely participate in classroom activities.

- Considering the nature of power relations, students decide to conform or to contest their positioning by the teacher in the classroom. Teachers should not give priority to certain identities due to different orientations including cultural, social, gender, racial, class and so on; instead they should provide an equitable situation in which identity negotiation is fostered and as a result this enhances learning outcomes in students and leads to their success in classroom community.

- Teachers should not divide students into lower-status and higher-status individuals; rather students have to be provided with opportunities to demonstrate their talents and obtain a sense of accomplishment through doing academic challenging tasks. This makes learners build a positive identity in the classroom and increases their self-confidence and skills such as problem-solving and risk-taking.

- Teachers should also notice and be sensitive to institutional practices that may impose undesirable identities on students and support making necessary institutional changes which may lead to constructing a positive identity in learners. For instance, teachers can consult to school authorities for providing appropriate environment, programs and facilities.

- According to Cummins (1996) when students feel supported in their self-worth, they have a much stronger sense of belonging in the community. Teachers need to recognize how powerful their discursive practices can be in helping students negotiate undesirable identities and leading to positive learning experiences. Teachers have to participate students in decision-making processes and by empowering them try to provide a learner-centered environment moving away from teacher-centeredness.

Finally, as it was said earlier, learner identity has opened up an extensive area of research both for language teachers and scholars to work on its various aspects trying to measure its impact on the teaching practices as well as learning outcomes. According to Norton (2006) if we take seriously the argument that the identity of the second language learner is not a personality variable but a socially and historically constructed relationship to both institutional and community practices, then it follows that teachers, researchers, administrators, testers, and policy makers are all implicated in the range of identities available to the second language learner. There is every indication that based on Norton (2006), the 
interest in second language identity will grow in momentum, enriching existing course of research and shaping new, exciting directions.

\section{REFERENCES}

[1] Atkinson, D. (1999). TESOL and culture. TESOL Quarterly, 33(4), 625-654.

[2] Bakhtin, M. (1981). The dialogic imagination: Four essays by M. M. Bakhtin. Austin: University of Texas Press.

[3] Benwell, B., \& Stokoe, E. (2006). Discourse and identity. Edinburgh: Edinburgh University Press Ltd

[4] Blackledge, A., \& Pavlenko, A. (2001). Negotiation of identities in multilingual contexts. The International Journal of Bilingualism, 5, 243-257.

[5] Bourdieu, P. (1984). Distinction: A social critique of the judgment of taste. London: Rutledge.

[6] Chavous, T. (2006). Ethnic Identity and Academic Achievement. Retrieved November 23, 2011from http://www.education.com/reference/article.

[7] Chen, X. \& Fredonia, S. (2010).Identity construction and negotiation within and across school communities: The case of one English-as-a-new-language (ENL) Student. Journal of Language, Identity, and Education, 9, 163-179.

[8] Cummins, J. (2000). Language, power and pedagogy: Bilingual children in the crossfire. Clevedon, England: Multilingual Matters.

[9] Duff, P., \& Uchida, Y. (1997). The negotiation of teachers' sociocultural identities and practices in postsecondary EFL classrooms. TESOL Quarterly, 31, 451-486.

[10] Falsafi, L., \& Coll, S. (2010). Learner identity: A sociocultural approach to how people recognize and construct themselves as learners. Unpublished ph.D dissertation. Barcelona: University of Barcelona

[11] Gee, J. P. (2001). Identity as an analytic lens for research in education. In W.C. Secada (Ed.), Review of research in education (pp. 99-125). Washington DC: American Education Research Association.

[12] Hawkins, M. (2004). Researching English language and literacy development in schools. Educational Researcher, 33, $14-25$.

[13] Joseph, J. E. (2004). Language and identity : National, ethnic, religious. New York: Palgrave Macmillan.

[14] Lam, W. S. E. (2000). L2 literacy and the design of the self: A case study of a teenager writing on the internet. TESOL Quarterly 34(3), 457-482.

[15] Lave, J., \& Wenger, E. (1991). Situated learning: Legitimate peripheral participation. Cambridge, England: Cambridge University Press.

[16] Mitchell, R., \& Myles, F. (2004). Second language learning theories (2nd ed.). New York, NY: Oxford University Press.

[17] Norton, B. (1995). Social identity, investment, and language learning. TESOL Quarterly, 29 (1), 9-31.

[18] Norton, B. (1997). Language, identity, and the ownership of English. TESOL Quarterly, 31 (3), 409-429.

[19] Norton, B. (2000). Identity and language learning: Gender, ethnicity and educational change. Harlow, England: Pearson Education.

[20] Norton, B. (2006). Identity: Second language. Encyclopedia of language and linguistics, 5, 502-508.

[21] Norton, B., \& Toohey, K. (2001). Changing perspectives on good language learners. TESOL Quarterly 35(2), 307-322.

[22] Norton Peirce, B., \& Stein, P. (1995). Why the "Monkeys Passage" bombed: Tests, genres, and teaching. Harvard Educational Review 65(1), 50-65.

[23] Osguthorpe, R. T. (2006). Learning that grows. Current developments in technology-assisted education. Retrieved October 26, 2011 from www.formatex.org/micte2006/pdf/1888-1892.pdf.

[24] Toohey, K., Day, E. \& Manyak, P. (2007). SL learners in the early school years: Idetity and mediated classroom practices. In J. Cummins and C. Davison (Eds.), International handbook of English language teaching. NY: Springer.

[25] Weedon, C. (1987). Feminist practice and poststructuralist theory ( $2^{\text {nd }}$ ed.). London: Blackwell.

[26] Wenger, E. (1998). Communities of practice: Learning, meaning, and identity. Cambridge, England: Cambridge University Press.

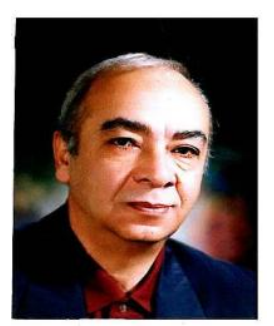

Parviz Maftoon is Associate Professor of teaching English at Islamic Azad University, Science and Research Branch, Tehran, Iran. He received his Ph.D. degree from New York University in 1978 in Teaching English to Speakers of Other Languages (TESOL). His primary research interests concern EFL writing, second language acquisition, SL/FL language teaching methodology, and language syllabus design. He has published and edited a number of research articles and books. He is currently on the editorial board of some language journals in Iran.

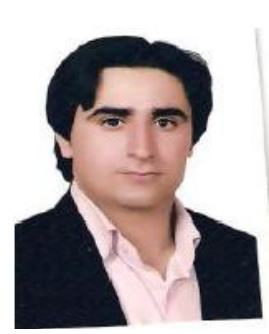

Saeid Najafi Sarem is a Ph.D student of TEFL in Islamic Azad University, Science and Research branch, Tehran, Iran. He is the head of Sharif Language Institute in Asadabad, Hamedan, and he is currently teaching in Azad and Payamnoor universities in Hamedan. He is interested in teaching methodology and second language acquisition (SLA) studies and has presented many articles in different national and international conferences. He has got some publications in different national and international journals as well. 


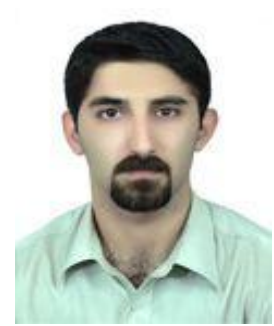

Hadi Hamidi has been teaching English for about 8 years at different institutes. He is currently a Ph.D. candidate of TEFL in Islamic Azad University, Science and Research branch, Tehran, Iran. He has carried out a number of researches, translated a couple of articles, and presented a number of papers in different conferences and seminars inside the country. His areas of interest include CALL, ESP and Language Assessment. 